\title{
Radiological Impact Assessment of Farm Soils and Ofada rice (Oryza sativa japonica) from Three Areas in Nigeria
}

\author{
S. K. Alausa ${ }^{1 *} \quad$ Bayo Adeyeloja ${ }^{2} \quad$ Kola Odunaike
}

\author{
${ }^{1 *}$ Department of Physics, Olabisi Onabanjo University, P. M. B.2002 Ago-Iwoye, Nigeria \\ ${ }^{1}$ *Corresponding authors: alausakunle @ yahoo.com \\ 1 *ORCID: 0000-0003-3748-243X \\ ${ }^{1}$ Email: kolaodunaike@ oouagoiwoye.edu.ng \\ ${ }^{1}$ ORCID: 0000-0001-7518-3049 \\ ${ }^{2}$ Physics Electronics Department, Yaba College of Technology, Yaba Lagos State, Nigeria \\ ${ }^{2}$ Email: bayo_ade@yahoo.com \\ ${ }^{2}$ ORCID: 0000-0001-9423-4753
}

Received 8/6/2019, Accepted 7/1/2020, Published 8/9/2020

\begin{abstract}
:
Oryza sativa japonica (ofada rice) is largely grown in Aramoko, Abakaliki and Ofada communities and consumed by both the poor and rich in Nigeria. A total of twenty ofada rice farmlands were identified in each study area and rice samples were randomly collected, thoroughly mixed to make a representative sample from each farmland. Soil samples were collected in each farm to a depth of $5-15 \mathrm{~cm}$ from at least eight different points and thoroughly mixed together to form a representative sample. The samples were thereafter taken to the laboratory for preparation and spectroscopic analysis. A well-calibrated $\mathrm{NaI}(\mathrm{Tl})$ gamma-ray detector was used in spectrometric analysis of the samples and descriptive statistics was used to analyze the results.

The respective mean ${ }^{40} \mathrm{~K},{ }^{238} \mathrm{U}$ and ${ }^{232} \mathrm{Th}$ activity concentrations in the rice were $261.8 \pm 52.5 \mathrm{~Bq} / \mathrm{kg}$, $9.6 \pm 1.2 \mathrm{~Bq} / \mathrm{kg}$ and $8.7 \pm 1.0 \mathrm{~Bq} / \mathrm{kg}$ (Ofada); $257.3 \pm 39.0 \mathrm{~Bq} / \mathrm{kg}, 9.3 \pm 1.1 \mathrm{~Bq} / \mathrm{kg}$ and $7.8 \pm 1.8 \mathrm{~Bq} / \mathrm{kg}$ (Abakaliki); and $248.2 \pm 54.8 \mathrm{~Bq} / \mathrm{kg}, 9.3 \pm 0.9 \mathrm{~Bq} / \mathrm{kg}$ and $7.6 \pm 1.5 \mathrm{~Bq} / \mathrm{kg}$ (Aramoko). The respective mean ${ }^{40} \mathrm{~K},{ }^{238} \mathrm{U}$ and ${ }^{232} \mathrm{Th}$ activity concentrations in the soils were $333.9 \pm 62.8 \mathrm{~Bq} / \mathrm{kg}, 11.1 \pm 1.1 \mathrm{~Bq} / \mathrm{kg}$ and $11.0 \pm 1.4 \mathrm{~Bq} / \mathrm{kg}$ (Ofada); $306.8 \pm 36.0 \mathrm{~Bq} / \mathrm{kg}, 10.7 \pm 0.8 \mathrm{~Bq} / \mathrm{kg}$ and $9.4 \pm 1.8 \mathrm{~Bq} / \mathrm{kg}$ (Abakaliki) and $321.8 \pm 42.4 \mathrm{~Bq} / \mathrm{kg}, 10.9 \pm 0.5 \mathrm{~Bq} / \mathrm{kg}$ and $9.5 \pm 0.6 \mathrm{~Bq} / \mathrm{kg}$ (Aramoko). The highest mean ingestion dose of $106.0 \pm 8.0 \mu \mathrm{Sv} / \mathrm{y}$ and outdoor effective dose of $32.4 \pm 3.40 \mu \mathrm{Sv} / \mathrm{y}$ were recorded in Ofada community. The highest mean ingestion cancer risk of $(0.33 \pm 0.004)$ $\mathrm{x} 10^{-3}$ was recorded in Aramoko. The results indicated significantly lower radionuclide ingestion dose than the world limit value of $290 \mu \mathrm{Sv} / \mathrm{y}$ and higher cancer risks than the UNSCEAR recommended limit of $0.29 \times 10^{-3}$, therefore consumption of ofada rice from the areas may not pose any serious health impact.
\end{abstract}

Keywords: Farm soils, Nigeria, Ofada rice, Producing areas, Radiological impact.

\section{Introduction:}

The formation of soil is due to the weathering of parent rocks in the earth crust that contains decay series ${ }^{238} \mathrm{U}$ and ${ }^{232} \mathrm{Th}$ and non-series ${ }^{40} \mathrm{~K}$ radionuclides since the creation of the earth. Natural terrestrial radioactivity is linked to the activity concentrations of the series and non-series decay radionuclides in the earth crust and soils. Humans are exposed to the terrestrial radioactivity through direct and indirect pathways from radionuclides in the earth crust $(1,2)$. It is obvious to note that farmers repeatedly used and exhausted few available farmlands thereby caused soil infertility and consequently reduced the annual farm yields. The soil infertility motivated farmers to use various form of fertilizers to supplement the nutrients in farms to increase the annual food crop yields. Fertilizers contain uranium, thorium and radium radionuclides and their application especially those with phosphate rocks enhances the activity concentrations of natural radionuclides in the soil $(3,4)$. The radionuclides in the soil are transferred into food crops through plant-root uptake and the subsequent health impact when ingested by a human is continuously causing concern to scientists all over the world. These natural radionuclides in soil find their ways into the 
root system, in the same manner, the nonradioactive elements enter the plant roots and transferred to the edible parts of food crops (5) and the consumption or intake of radioactive contaminated foods is one of the sources of internal radiation exposure to human(6).

The United Nation's advocacy against the consumption of food contaminated with radionuclides has motivated various authors in the field of environmental radioactivity to continuously assess the health impact of radionuclides in various food matrices across the globe. In fact, the potential dangers envisaged in internal radiation exposure of human have encouraged many authors to study the radioactivity levels in various food items from different parts of the world (7-12). The estimated amounts of each radionuclide that are absorbed into the human body organs can be determined if the concentration of different radionuclides in a food item is measured and the consumption rates of the foodstuff by individuals are known. In other words, the level of radiation dose to man depends on the quantity of food consumed and the concentrations of the radionuclides in such foodstuffs.

Food in liquid or solid form is the foremost necessity among the needs for survival of human. It provides nourishment, energy and vitality. The food contains nutrients like carbohydrate, fat and oil for energy and heat; protein for body-building; minerals and vitamins for body protection and proper functioning of the body. In Nigeria, carbohydrate such as cereals and tubers constitute the most important food basket (13) and rice (cereal food crop) is commonly consumed by both the rich and poor. Although rice is grown in almost all the parts of the country the most popular areas that produce ofada rice varieties are Abakaliki in Ebonyi State, Ofada in Ogun State and Aramoko in Ekiti State. The geology of each of the study area is shown in Fig. 1.

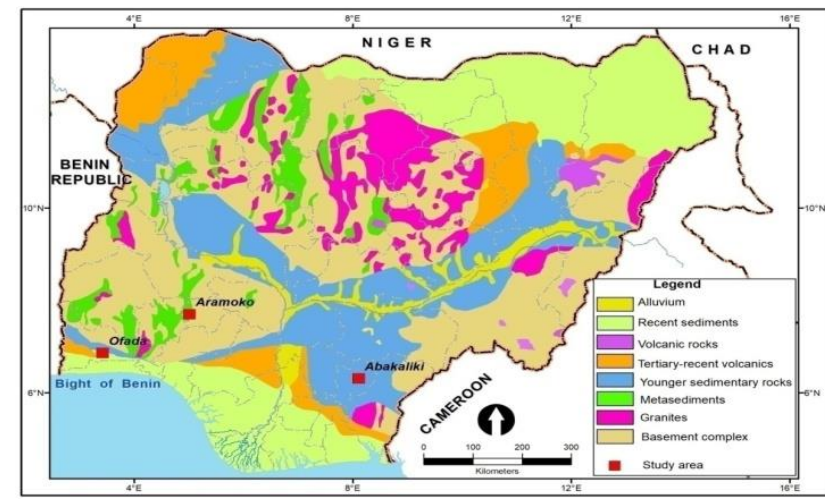

Figure1. Generalized geological map of Nigeria showing the study areas (14)
The three areas are characterized by different geological settings. The study is therefore aimed at measuring the natural radioactivity in the rice and farm soils from the three areas using gamma ray-spectrometer and determining the resulting health effect on human.

Omotayo et al. (15) reported that a farmer from each of the study areas produces as much as 136 metric tons of ofada rice per annum. Ofada rice is recently becoming famous and prominence among the species of rice because of its natural taste that inspired high demand for consumption (16). This is because the mode of preparation, serving and the emotional value obtained in eating ofada rice is traced to its originality that connects people to their cultural heritage and food habit (17). Osaretin et al. (18), reported that ofada rice contains higher protein, fat, and fiber than imported rice (aroso rice). However, there is a need to ensure compliance with the United Nation's advocacy for food free from contaminants by examining the radioactivity levels. The aim of the study, therefore, is to determine the radiological impact due to the soil and the ofada rice produced in the three communities, consumed by the people from the three communities and sell to other areas in Nigerian for consumption.

\section{Materials and Methods: Rice Sampling}

Rice samples were collected from three study areas including Aramoko, Abakaliki and Ofada, in Ekiti, Ebonyi and Ogun States respectively. The three areas are known for the large production of ofada rice (Oryza sativa japonica) in Nigeria. Twenty ofada rice farmlands in each study area were identified and sampling was carried out in the farmlands during the harvesting period to facilitate and ensure site preciseness. Sampling was carried out randomly at different points and mixed to obtain a representative sample in each farmland. Thus, a total of twenty rice samples were collected in each study area. The samples collected in each farm were carefully packed in well-labeled polythene bags before being transported to a radiometric laboratory for preparation and spectroscopic measurements.

\section{Soil Sampling}

Soil samples were collected from the same twenty ofada rice farmlands. Soil samples were collected at eight or ten points and the same spots where the rice samples were taken. Thereafter, the soil samples were thoroughly mixed to obtain a representative sample. This gave a total number of twenty soil samples each collected for Aramoko, 
Abakaliki and Ofada communities. The soil samples from farms were carefully packed in black polythene bags and properly labeled. Thereafter, all the soil samples were transported to a radiometric laboratory for preparation and spectroscopic measurement.

\section{Food sample preparation}

The study focuses on human ingestion of rice grown and consumed hence only the edible portions of the rice samples were prepared for spectrometric analysis. The rice shafts were removed and the edible parts were thereafter ovendried at $110 \stackrel{\circ}{C}$ to attain constant mass. The rice samples were then milled and sieved with a $2.0 \mathrm{~mm}$ mesh sieve to attain the same matrix as the standard food sample before homogenized. 200g each of the rice sample was packed into uncontaminated geometry sample containers of uniform sizes. The containers were then sealed for about 28 days (4 weeks) to allow for secular equilibrium between ${ }^{226} \mathrm{Ra}$ and ${ }^{228} \mathrm{Ra}$ and their respective progenies before gamma spectroscopy.

\section{Soil sample preparation}

The soil samples were crushed, grounded and sieved with a $2.0 \mathrm{~mm}$ mesh sieve, after drying for about twenty days at room temperature. Thereafter the soil samples were oven-dried at 110 $\stackrel{\circ}{C}$ $C$ to attain constant mass. $200 \mathrm{~g}$ of each sample was transferred into uncontaminated empty cylindrical plastic containers of uniform sizes and then sealed for about four weeks like the food samples. This was to allow secular equilibrium between ${ }^{226} \mathrm{Ra}$ and ${ }^{228} \mathrm{Ra}$ and their respective progenies before gamma spectroscopy.

\section{Radioactivity determination}

The sample analysis was carried out using a single crystal $5.0 \mathrm{~cm} \times 5.0 \mathrm{~cm} \mathrm{NaI}(\mathrm{Tl})$ detector, manufactured by Scintitech Instrument, USA, coupled with a Hamamatsa (R1306NSV3068) photomultiplier tube and a Multichannel Analyzer, MCA (2100R:01) manufactured by Price gamma Technology, USA that required no inbuilt PC memory for operation. The MCA with attached Quantum MCA software is capable of performing automatic adjustment of the detector bias and amplifier gain. All calibration functions were made through the software. The detector has adequate energy resolution (FWHM) of about $8.0 \%$ in $0.662 \mathrm{MeV}\left({ }^{137} \mathrm{Cs}\right)$ to distinguish the gamma-ray energies of radionuclides in each sample. The ${ }^{214} \mathrm{Bi}$ with peak gamma-ray energy of $1.760 \mathrm{MeV}$ was selected to provide an estimate of ${ }^{226} \mathrm{Ra}\left({ }^{238} \mathrm{U}\right)$ in the sample, the radionuclide ${ }^{208} \mathrm{Tl}$ with gamma-ray energy $2.615 \mathrm{MeV}$ was selected for estimating ${ }^{232} \mathrm{Th}$. The ${ }^{40} \mathrm{~K}$ radionuclide was determined by measuring the $1.460 \mathrm{MeV}$ gamma-ray emitted during its decay. Each sample was counted for 36000 seconds. The expression for activity concentration is given by (19)

$$
A(B q / k g)=\frac{N}{\varepsilon \times I_{\gamma} \times t \times m_{s}}
$$

where $A$ represents activity concentration in $\mathrm{Bq} / \mathrm{Kg}$; $\mathrm{N}$, is a number representing the count rate under the photo peak, $\varepsilon$ in cps/Bq represents the efficiency of radionuclide at the specific $\gamma$-ray energy, $I_{\gamma}$ is a number representing the gamma yield, $\mathrm{m}_{\mathrm{s}}$ represents the mass of the sample in $\mathrm{kg}$ and $\mathrm{t}$ is representing time.

\section{Effective dose due to ingestion of food crop}

According to Jibiri et al. (20), the effective dose due to ingestion of food is given by:

$$
H_{T, r}=\sum\left(U^{i} \times C_{r}^{i}\right) \times g_{T . r}
$$

Where the coefficients $U^{i}$ and $C_{r}^{i}$ denote the consumption rate $(\mathrm{kg} / \mathrm{yr})$ and activity concentration of the radionuclide $(\mathrm{Bq} / \mathrm{kg})$ respectively and $g_{T} r$ is the dose coefficient for ingestion of radionuclide $r$ (Sv $\left.\mathrm{Bq}^{-1}\right)$. The values of $g_{T r}$ for ${ }^{40} \mathrm{~K},{ }^{226} \mathrm{Ra},{ }^{232} \mathrm{Th}$ and ${ }^{137} \mathrm{Cs}$ are $5.9 \times 10^{-9} \mathrm{~Sv} \mathrm{~Bq}^{-1}, 4.8 \times 10^{-8} \mathrm{~Sv} \mathrm{~Bq}^{-1}, 2.3 \times 10^{-}$ ${ }^{7} \mathrm{~Sv} \mathrm{~Bq}^{-1}$ and $1.3 \times 10^{-8} \mathrm{~Sv} \mathrm{~Bq}^{-1}$ respectively for members of the public (adult) (21). These conversion factors were used to determine the effective doses due to dietary intake of radionuclides contained in ofada rice from the study areas. The rice consumption rate $\left(U^{i}\right)$ value of $26.35 \mathrm{~kg} /$ Person in Nigeria (22) was used in the study.

\section{Absorbed and outdoor effective dose rates}

The absorbed gamma dose rates $D_{R}$ in the air at $1 \mathrm{~m}$ above the ground level were calculated using (4):

$$
D_{R}=0.427 C R a+0.623 C T h+0.043 C K \quad 3
$$

where $D_{R}$ is the dose rate in $\mathrm{nGy} / \mathrm{h}$ and $C_{R a}, C_{T h}$ and $C_{K}$ are the activity concentrations $(\mathrm{Bq} / \mathrm{kg})$ of radium $\left({ }^{226} \mathrm{Ra}\right)$, thorium $\left({ }^{232} \mathrm{Th}\right)$, and potassium $\left({ }^{40} \mathrm{~K}\right)$, respectively.

The determination of absorbed gamma dose exposure of human is not sufficient to quantify the radiological health effect. However, the better feature in quantifying the radiological health impact from the soil is by determining the effective dose rates. The effective dose rate due to soil samples from the farmlands in each site was calculated using (7):

$$
H_{R}=D_{R} \times 0.2 \times 0.7 \times 8760
$$

Where $\mathrm{D}$ is the absorbed gamma dose rate in $(\mathrm{nGy} / \mathrm{h}) ; 0.2$ is the occupancy factor; $0.7 \mathrm{~Sv} / \mathrm{Gy}$ is 
the conversion factor and $8760 \mathrm{~h} / \mathrm{y}$ as recommended by UNSCEAR and reported in (4).

\section{Lifetime cancer risks due to ingestion of ofada and background radiation exposure from farm}

The irregular cells growth either due to the action of carcinogens or likely exposure to gammarays may end up in the creation of tumor and later develops to cancerous cells. The cancerous cells can attack the adjoining body system and later spread to different organs of the body. A lifetime cancer risk is defined as the probability of a member of a population dying from cancer at a lifetime due to internal or external radiation exposures (23). The lifetime cancer risks associated with intake of rice in the study was determined from the cancer risk coefficients for ingestion of radionuclides and percapita intake of the radionuclides given by (24):

$R_{F}=\sum r_{i} I_{i}$

and

$I_{i}=A_{i} C T$

$\mathrm{r}_{\mathrm{i}}$ is the cancer risk coefficient for $\mathrm{i}^{\text {th }}$ radionuclide, $\mathrm{I}_{\mathrm{i}}$ is the per-capital activity intake of the radionuclide, $A_{i}$ is the activity concentration of the $i^{\text {th }}$ radionuclide, $\mathrm{C}$ is the food consumption rate and $\mathrm{T}$ is the average lifetime expectancy. The average lifetime expectancy at birth in Nigeria is 45.5 years (24) and the values of risk coefficients, $r$ for ${ }^{226} \mathrm{Ra}$, ${ }^{232} \mathrm{Th}$ and ${ }^{40} \mathrm{~K}$ are $9.56 \times 10^{-9} \mathrm{~Bq}^{-1}, 2.45 \times 10^{-9} \mathrm{~Bq}^{-1}$ and $5.89 \times 10^{-10} \mathrm{~Bq}^{-1}(25)$.

The cancer risks due to the external radiation exposure from farm soils were evaluated using the activity concentrations of ${ }^{40} \mathrm{~K},{ }^{226} \mathrm{Ra}$, and ${ }^{232} \mathrm{Th}$ radionuclides in the farm soils and carcinogenicity radionuclide slope factors for environmental exposure to radionuclides by the United States Environmental Protection Agency and the average life expectancy (25):

$R_{S}=\sum r_{i} A T$

Where $\mathrm{A}$ is the activity concentration in $\mathrm{Bq} / \mathrm{kg}, \mathrm{r}_{\mathrm{i}}$ is the cancer mortality risk coefficient for $\mathrm{i}^{\text {th }}$ radionuclide and $\mathrm{T}$ is the average life expectancy. The value of $\mathrm{r}$ for ${ }^{226} \mathrm{Ra},{ }^{232} \mathrm{Th}$ and ${ }^{40} \mathrm{~K}$ are $1.33 \times 10^{-}$ ${ }^{17} \mathrm{~kg} / \mathrm{Bq}-\mathrm{s}, 1.97 \times 10^{-19} \mathrm{~kg} / \mathrm{Bq}-\mathrm{s}$ and $4.66 \times 10^{-16} \mathrm{~kg} / \mathrm{Bq}-$ $\mathrm{s}$ respectively.

The total cancer risk, $R_{T}$ was evaluated by summation of the cancer risks due to the ingestion of ofada rice and the radiation exposure from farm soils:

$R_{T}=R_{S}+R_{F}$

where $\mathrm{R}_{S}$ is the mean cancer risks due to radioactivity in soils and $R_{F}$ is the mean cancer risks due to radioactivity in food ingestion.

\section{Radiological hazard indices}

Radiological hazard index isa concept used to assess the radiation hazard associated with natural radionuclides in environmental matrices. The hazard indices are useful tools in determining the radiological suitability of soil or other environmental substances for building construction. The radiological parameters including radium equivalent activity $\left(\mathrm{Ra}_{\mathrm{eq}}\right)$, internal hazard index $\left(\mathrm{H}_{\mathrm{in}}\right)$, external hazard index $\left(\mathrm{H}_{\mathrm{ex}}\right)$ and gamma index $\left(\mathrm{I}_{\gamma}\right)$ are determined to appraise the radiological health risks due to radiation exposure from soils.

\section{Radium equivalent activity}

Radium equivalent activity is used to assess the hazards associated with materials that contain ${ }^{226} \mathrm{Ra},{ }^{232} \mathrm{Th}$ and ${ }^{40} \mathrm{~K}$ in $\mathrm{Bq} / \mathrm{kg}$ in materials used in building and it is determined on the assumption that $10 \mathrm{BqKg}^{-1}$ of ${ }^{226} \mathrm{Ra}, 7 \mathrm{BqKg}^{-1}$ for ${ }^{232} \mathrm{Th}$ and 130 $\mathrm{Bq} / \mathrm{kg}$ for ${ }^{40} \mathrm{~K}$ produce the same gamma-ray dose rate (26). The radium equivalent activity was calculated using (7):

$R a_{a q}=A_{R a}+1.43 A_{T h}+0.077 A_{K}$

where $A_{R a}, A_{T h}$ and $\mathrm{A}_{k}$ are the activity concentrations of ${ }^{226} \mathrm{Ra},{ }^{232} \mathrm{Th}$ and ${ }^{40} \mathrm{~K}$ respectively.

\section{External hazard index}

The external hazard index $\left(\mathrm{H}_{e x}\right)$ is a radiation criterion used to evaluate hazard level from natural gamma radiation due to exposure to radon and its decay progeny (27) and it was calculated using (7):

$H_{e x}=\frac{A_{R a}}{370}+\frac{A_{T h}}{259}+\frac{A_{K}}{4810}$

where $\mathrm{A}_{\mathrm{Ra}}, \mathrm{A}_{\mathrm{Th}}$ and $\mathrm{A}_{K}$ are the activity concentrations of ${ }^{226} \mathrm{Ra},{ }^{232} \mathrm{Th}$ and ${ }^{40} \mathrm{~K}$ respectively.

\section{Internal hazard index}

The internal hazard index is also a radiation criterion due to exposure to radon and its decay progeny (27) and it was using (7):

$H_{\text {in }}=\frac{A_{R a}}{185}+\frac{A_{T h}}{259}+\frac{A_{K}}{4810}$

where $\mathrm{A}_{\mathrm{Ra}}, \mathrm{A}_{\mathrm{Th}}$ and $\mathrm{A}_{K}$ are the activity concentrations of ${ }^{226} \mathrm{Ra},{ }^{232} \mathrm{Th}$ and ${ }^{40} \mathrm{~K}$ respectively.

\section{Gamma index}

The gamma index $\left(I_{\gamma}\right)$ is a hazard parameter used to correlate the annual dose rate due to external gamma radiation. It is used only as screening tool for identifying materials that might pose health risk when used as construction materials (28). The gamma index was calculated using the model from European Commission (29).

$I_{\gamma}=\frac{A_{R a}}{300}+\frac{A_{T h}}{200}+\frac{A_{K}}{3000}$ 
where $\mathrm{A}_{\mathrm{Ra}}, A_{T h}$ and $A_{K}$ are the activity concentrations of ${ }^{226} \mathrm{Ra},{ }^{232} \mathrm{Th}$ and ${ }^{40} \mathrm{~K}(\mathrm{~Bq} / \mathrm{kg})$ respectively

\section{Results and discussion:}

Activity concentrations in rice from the study areas

The activity concentrations of ${ }^{40} \mathrm{~K},{ }^{226} \mathrm{Ra}$ and ${ }^{232} \mathrm{Th}$ were calculated using Eq. 1 and the results are presented in Table1. The results indicated that the natural radionuclides were present in the rice samples and no trace of artificial radionuclide was detected. It was observed that ${ }^{40} \mathrm{~K}$ exhibited the highest activity concentration in each rice sample investigated in the study. Similar findings of ${ }^{40} \mathrm{~K}$ exhibiting the highest concentration in radioactivity were reported (6). The radioactivity levels obtained in the ofada rice from Ofada community were slightly higher than any of the other two communities. However, the ${ }^{226} \mathrm{Ra}$ and ${ }^{232} \mathrm{Th}$ activity concentrations obtained in rice from Abakaliki and Aramoko were very similar. This is assumed to be due to the radionuclide absorption capability of the ofada rice irrespective of the geological formations of the different communities. The mean activity concentrations of $89.3 \pm 6.2 \mathrm{~Bq} / \mathrm{kg}$ for ${ }^{40} \mathrm{~K}, 2.8 \pm 0.7 \mathrm{~Bq} / \mathrm{kg}$ for ${ }^{226} \mathrm{Ra}$ and $7.5 \pm 2.7 \mathrm{~Bq} / \mathrm{kg}$ for ${ }^{232} \mathrm{Th}$ reported for paddy rice from Kampung Permatang TokLabu in Malaysia (30) were lower than the values obtained for ofada rice from all the three study areas. The average activity concentration of ${ }^{40} \mathrm{~K}$ reported as $109.9 \mathrm{~Bq} / \mathrm{kg}$ in rice (Siam species) (31) was about one-half less than the values obtained from each of the three study areas. The respective values of ${ }^{226} \mathrm{Ra}$ and ${ }^{232} \mathrm{Th}$ concentrations reported for rice (White glutinous species) (31) were higher than the values in the present study. Mlwilo et al., (8), reported radioactivity levels in rice from Tanzania as $24.7 \mathrm{~Bq} / \mathrm{kg}$ for ${ }^{40} \mathrm{~K}, \quad 5.02 \mathrm{~Bq} / \mathrm{kg}$ for ${ }^{226} \mathrm{Ra}$ and $3.8 \mathrm{~Bq} / \mathrm{kg}$ for ${ }^{232} \mathrm{Th}$. These values were lower than the corresponding values in the present study.

\section{Activity concentrations in farm soil from the study areas}

The activity concentrations of ${ }^{40} \mathrm{~K},{ }^{226} \mathrm{Ra}$ and ${ }^{232} \mathrm{Th}$ in the farm soils in the study areas shown in Table 2 varied from $238.5 \mathrm{~Bq} / \mathrm{kg}$ (Abakaliki) to $450.5 \mathrm{~Bq} / \mathrm{kg}$ (Ofada); $8.7 \mathrm{~Bq} / \mathrm{kg}$ (Aramoko) to $12.9 \mathrm{~Bq} / \mathrm{kg}$ (Ofada) and $6.2 \mathrm{~Bq} / \mathrm{kg}$ (Abakaliki) to $13.0 \mathrm{~Bq} / \mathrm{kg}$ (Abakalilki) respectively. Generally, the radioactivity levels in soils reported in studies from other countries were higher than the values obtained in the present study. For instance, the activity concentrations in the soils around the proposed site of Lambapur Peddagattu and Serpally India were $807.08 \pm 255.87 \mathrm{~Bq} / \mathrm{kg}, \quad 48.07 \pm 22.30 \quad \mathrm{~Bq} / \mathrm{kg}$ and $230.77 \pm 89.26 \mathrm{~Bq} / \mathrm{kg}$ for ${ }^{40} \mathrm{~K},{ }^{226} \mathrm{Ra}\left({ }^{238} \mathrm{U}\right)$ and ${ }^{232} \mathrm{Th}$ respectively (32). Also the ${ }^{40} \mathrm{~K},{ }^{226} \mathrm{Ra}$ and ${ }^{232} \mathrm{Th}$ activity concentrations in the agricultural soils from the State of Kedah, North of Malaysia were $325 \pm 9.83 \mathrm{~Bq} / \mathrm{kg}, \quad 102.08 \pm 3.96 \mathrm{~Bq} / \mathrm{kg} \quad$ and $133.96 \pm 2.92 \mathrm{~Bq} / \mathrm{kg}$ respectively (4) while the ${ }^{40} \mathrm{~K}$, ${ }^{226} \mathrm{Ra}\left({ }^{238} \mathrm{U}\right)$ and ${ }^{232} \mathrm{Th}$ activity concentrations in the soil samples from the historical city Panipat India were $291.06 \pm 0.57 \mathrm{~Bq} / \mathrm{kg}, \quad 30.24 \pm 0.53 \mathrm{~Bq} / \mathrm{kg}$ and $29.89 \pm 0.61 \mathrm{~Bq} / \mathrm{kg}$ respectively (33). The activity concentrations in the soils from Chikun Kaduna Metropolis were $459.56 \mathrm{~Bq} / \mathrm{kg}$ for ${ }^{40} \mathrm{~K}, 62.28 \mathrm{~Bq} / \mathrm{kg}$ for ${ }^{226} \mathrm{Ra}$ and $155.34 \mathrm{~Bq} / \mathrm{kg}$ for ${ }^{232} \mathrm{Th}$ (34). The activity concentrations in the soils of few areas in Nigeria were reported as $180.5 \pm 16.0 \mathrm{~Bq} / \mathrm{kg}$ for ${ }^{40} \mathrm{~K}$, $22.5 \pm 3.8 \mathrm{~Bq} / \mathrm{kg}$ for ${ }^{226} \mathrm{Ra}$ and $38.5 \pm 6.1 \mathrm{~Bq} / \mathrm{kg}$ (35); $180.5219 .8 \mathrm{~Bq} / \mathrm{kg}$ for ${ }^{40} \mathrm{~K}, 20.3 \mathrm{~Bq} / \mathrm{kg}$ for ${ }^{226} \mathrm{Ra}$ and $21.1 \mathrm{~Bq} / \mathrm{kg}$ for ${ }^{232} \mathrm{Th}(36)$ and $352.34 \pm 18.67 \mathrm{~Bq} / \mathrm{kg}$ for $\quad{ }^{40} \mathrm{~K}, \quad 19.86 \pm 2.56 \mathrm{~Bq} / \mathrm{kgfor}^{226} \mathrm{Raand}$ $14.2 \pm 0.87 \mathrm{~Bq} / \mathrm{kg}$ for ${ }^{232} \mathrm{Th}(37)$ were all higher than the values obtained in the present study.

Table 1. Activity concentrations of ${ }^{40} \mathrm{~K},{ }^{226} \mathrm{Ra}$ and ${ }^{232} \mathrm{Th}(\mathrm{Bq} / \mathrm{kg})$, effective dose rates $\left(\mu \mathrm{Svy} \mathrm{y}^{-1}\right)$ and cancer risks in ingestion of rice from the three communities

\begin{tabular}{lcllllll}
\hline Community & $\begin{array}{c}\text { No of } \\
\text { farmlands }\end{array}$ & & ${ }^{40} \mathrm{~K}$ & ${ }^{226} \mathrm{Ra}$ & ${ }^{232} \mathrm{Th}$ & $\begin{array}{c}\text { Effective dose } \\
\text { rates }\end{array}$ & $\begin{array}{c}\text { Cancer risk } \\
\left(\mathrm{x} 10^{-3}\right)\end{array}$ \\
\hline Ofada & 20 & Range & $201.1-330.5$ & $8.2-11.3$ & $7.2-10.2$ & $93.7-118.4$ & $0.28-0.38$ \\
& & Mean $\pm \sigma$ & $261.8 \pm 37.9$ & $9.6 \pm 1.0$ & $8.7 \pm 0.9$ & $105.6 \pm 8.2$ & $0.32 \pm 0.03$ \\
Abakaliki & 20 & Range & $208.5-321.5$ & $7.5-11.8$ & $5.0-10.3$ & $83.0-118.0$ & $0.27-0.37$ \\
& & Mean $\pm \sigma$ & $257.2 \pm 35.5$ & $9.3 \pm 0.9$ & $7.8 \pm 1.5$ & $98.1 \pm 10.2$ & $0.31 \pm 0.03$ \\
Aramoko & \multirow{2}{*}{20} & Range & $201.3-340.1$ & $6.8-11.2$ & $5.6-8.9$ & $77.4-114.0$ & $0.24-0.36$ \\
& & Mean $\pm \sigma$ & $248.2 \pm 40.1$ & $9.2 \pm 1.1$ & $7.6 \pm 0.8$ & $96.2 \pm 8.5$ & $0.30 \pm 0.03$ \\
\hline
\end{tabular}

$*^{*} \sigma$ is the standard deviations

Effective dose rates due to the consumption of ofada rice

Eq. 2 was used to determine the effective dose in ingestion of ofada rice from the study areas. The mean effective doses obtained in the study indicated that Abakaliki and Aramoko have very close values of $98.1 \pm 10.2 \mu \mathrm{Sv} / \mathrm{y}$ and $96.2 \pm 8.5 \mu \mathrm{Sv} / \mathrm{y}$ respectively and the highest value of $105.60 \pm 8.2 \mu \mathrm{Sv} / \mathrm{y}$ was obtained in rice from Ofada community. 
The effective dose of $294.3 \pm 49.8 \mu \mathrm{Sv} / \mathrm{y}$ due to the ingestion of rice reported for Kampung Peratang Malaysia (30) was about three times higher in magnitude than the value got in ofada rice from Ofada Community. The respective effective doses of $153.4 \pm 332.2 \mu \mathrm{Sv} / \mathrm{y}$ and $236.1 \pm 26.8 \mu \mathrm{Sv} / \mathrm{y}$ were reported for rice from other two areas, Sungai Besar and Kampung Sakan in Malaysia (30). The effective dose from each of the two reported areas in Malaysia was higher than the values reported in the present study. The estimated effective dose obtained in the study was higher than $64.23 \mu \mathrm{Sv} / \mathrm{y}$ (12) reported for Bangladesh but lower than the world average value of $290 \mu \mathrm{Sv} / \mathrm{y}$ (7).

Although the effective dose of the rice from the Ofada community was higher than the values obtained in Abakaliki and Aramoko, the radiological impact may depend on the frequency and quantity of the rice consumed. Ofada rice constitutes the major food types of nutritive importance in Nigeria and is consumed mostly during ceremonies and festivals. Therefore expected radiological effects due to ingestion of rice from the study areas depend largely and directly on the reality of dietary habits and the food choices of individuals.

\section{Absorbed and outdoor effective doses in farm soils}

Eqs.3 and 4 were respectively used to determine the gamma absorbed dose and effective dose rates in the farm soils from the study areas.

The mean absorbed dose rates $(\mathrm{nGy} / \mathrm{h})$ in the air at $1.0 \mathrm{~m}$ above the ground determined in farm soils at each study area are shown in Table2. The mean absorbed dose in the soil samples obtained in Ofada community was about $4.0 \mathrm{nGy} / \mathrm{h}$ greater than the value obtained in Aramoko and almost 2.0nGy/h higher than the value obtained in Abakaliki. However, the absorbed dose value in the soil samples in each of the study areas was far below the world average value of $59.0 \mathrm{nGy} / \mathrm{h}(7)$.

The effective dose rate was $0.032 \pm 0.003 \mathrm{mSv} / \mathrm{y}$ at Ofada, $\quad 0.029 \pm 0.002 \mathrm{mSv} / \mathrm{y}$ at Abakaliki and $0.030 \pm 0.002 \mathrm{mSv} / \mathrm{y}$ at Aramoko. Each of these values was ten times lower in magnitude than the world average value of $0.30 \mathrm{mSv} / \mathrm{y}$ (38). The outdoor effective doses received from farm soils by the local population in each of the study areas were low and insignificant radiological health burden could only be expected.

The degree of the association between the outdoor effective dose due to the farm soils and effective dose due to ingestion of the rice from the study areas was determined using statistical analysis (Pearson's rank correlation).Fig. 2 shows the regression lines and the correlation coefficients of
0.61 for Ofada, 0.42 for Abakalilki and 0.22 for Aramoko. The statistical analysis indicated that the correlation between the outdoor effective dose and effective dose due to ingestion of ofada rice at Ofada community showed a significant coefficient while the two others indicated low coefficients.
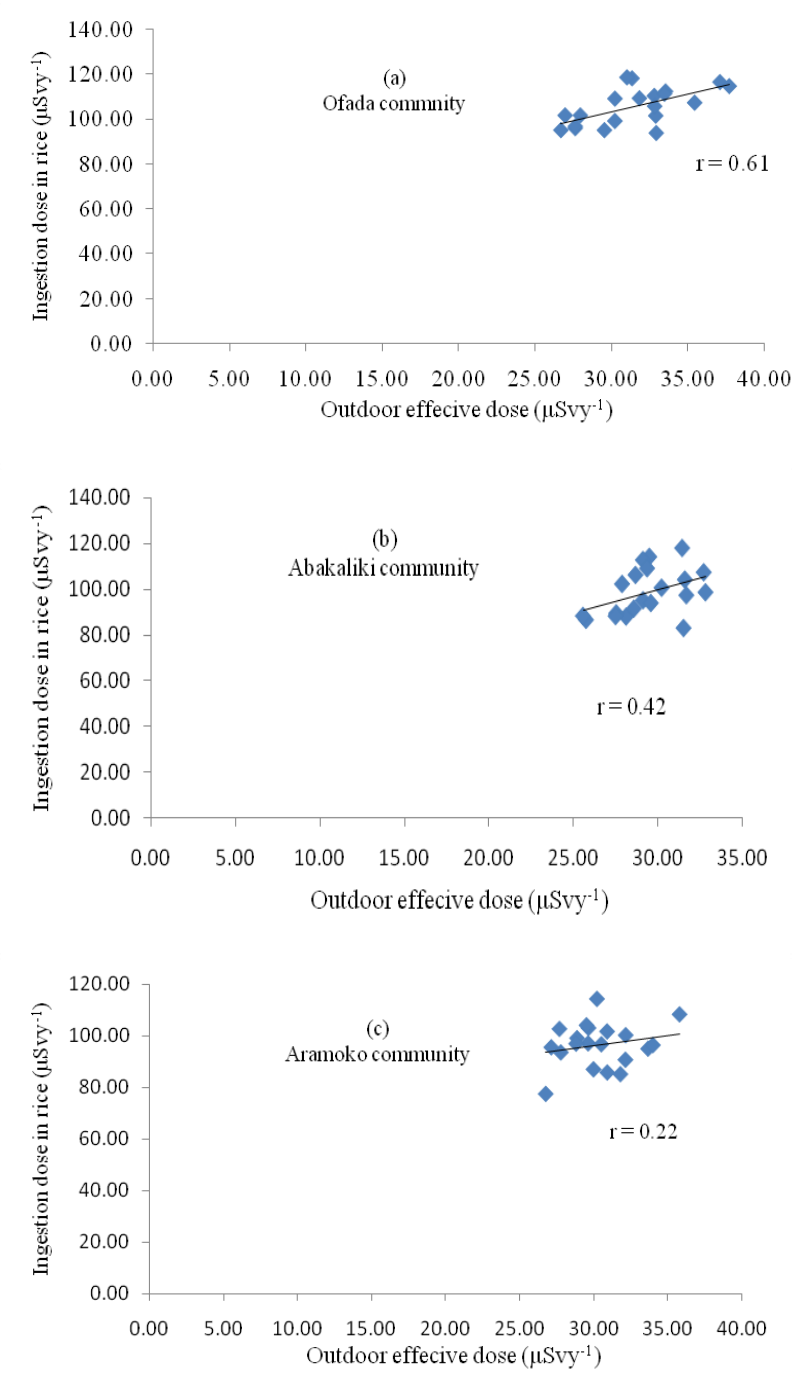

Figure 2.Correlation between outdoor effective and ingestion doses in (a) Ofada (b) Abakaliki (c) Aramoko communities

\section{Lifetime cancer risks due to ingestion of rice and exposure from farm soils}

Using eqs. 5 and6, the cancer risks due to ingestion of rice were evaluated and the results are presented in Table 1 for Ofada, Abakaliki and Aramoko communities as $(0.32 \pm 0.03) \times 10^{-3}$, $(0.31 \pm 0.03) \quad \times 10^{-3}$ and $(0.30 \pm 0.03) \times 10^{-3}$ respectively. The cancer risks resulting from the ingestion of ofada rice from the study areas were almost the same. However, the cancer risk due to ingestion of the ofada rice from each community was slightly higher than the value of $0.29 \times 10^{-3}$ reported by (12). 
Eq.7 was used to determine the cancer risks due to background radiation exposure of individuals from each of the study areas and the results are presented in Table 2 as $(0.22 \pm 0.04) \times 10^{-3},(0.20 \pm 0.02) \times 10^{-3}$ and $(0.22 \pm 0.03) \times 10^{-3}$ for Ofada, Abakaliki and Aramoko communities respectively. The cancer risk value obtained in each study area is lower than the
UNSCEAR recommended value of $0.29 \times 10^{-3}$ reported by $(7,39)$.

Eq. 8 was used to determine the total cancer risks, $\mathrm{R}_{\mathrm{T}}$ due to ingestion of rice and gamma exposure from the farm soils in the three study areas and the results were $0.54 \times 10^{-3}, 0.51 \times 10^{-3}$ and 0.52 $\mathrm{x} 10^{-3}$ for Ofada, Abakaliki and Aramoko communities respectively.

Table2. Activity concentrations of ${ }^{40} \mathrm{~K},{ }^{226} \mathrm{Ra}$ and ${ }^{232} \mathrm{Th}$ radionuclides, gamma absorbed and outdoor effective doses in farm soil and cancer risks from the three communities

\begin{tabular}{|c|c|c|c|c|c|c|c|c|}
\hline \\
\hline Community & $\begin{array}{l}\text { No of } \\
\text { farmlands }\end{array}$ & & $\begin{array}{l}{ }^{40} \mathrm{~K} \\
(\mathrm{~Bq} / \mathrm{kg})\end{array}$ & $\begin{array}{l}{ }^{226} \mathrm{Ra} \\
(\mathrm{Bq} / \mathrm{kg})\end{array}$ & $\begin{array}{l}{ }^{232} \mathrm{Th} \\
(\mathrm{Bq} / \mathrm{kg})\end{array}$ & $\begin{array}{l}\text { Gamma } \\
\text { dose } \\
(\mathrm{nGy} / \mathrm{h})\end{array}$ & $\begin{array}{l}\text { Effective } \\
\text { dose(mSv } \\
\text { /y) }\end{array}$ & $\begin{array}{r}\text { Cancer } \\
\text { risk } \\
\left(\mathrm{x} 10^{-3}\right)\end{array}$ \\
\hline \multirow[t]{2}{*}{ Ofada } & \multirow[t]{2}{*}{20} & Range & $243.7-450.5$ & $9.0-12.9$ & $8.2-11.2$ & $21.7-30.7$ & $0.027-0.038$ & $0.16-0.30$ \\
\hline & & $\begin{array}{c}\text { Mean } \pm \\
\sigma\end{array}$ & $333.9 \pm 56.0$ & $11.1 \pm 1.0$ & $9.9 \pm 0.9$ & $25.6 \pm 2.6$ & $0.032 \pm 0.003$ & $0.22 \pm 0.04$ \\
\hline \multirow[t]{2}{*}{ Abakaliki } & \multirow[t]{2}{*}{20} & Range & $238.5-350.1$ & 8.9-11.9 & $6.2-13.0$ & $20.8-26.7$ & $0.026-0.033$ & $0.16-0.23$ \\
\hline & & $\begin{array}{c}\text { Mean } \pm \\
\sigma\end{array}$ & $306.9 \pm 30.7$ & $10.7 \pm 0.9$ & $9.4 \pm 1.4$ & $24.0 \pm 16.9$ & $0.029 \pm 0.002$ & $0.20 \pm 0.02$ \\
\hline \multirow[t]{2}{*}{ Aramoko } & \multirow[t]{2}{*}{20} & Range & $265.3-420.5$ & $8.7-12.2$ & $8.3-10.7$ & $21.8-29.1$ & $0.027-0.036$ & $0.18-0.28$ \\
\hline & & $\begin{array}{c}\text { Mean } \pm \\
\sigma\end{array}$ & $321.8 \pm 43.7$ & $10.8 \pm 0.9$ & $9.5 \pm 0.7$ & $24.8 \pm 1.9$ & $0.030 \pm 0.002$ & $0.22 \pm 0.03$ \\
\hline
\end{tabular}

* $\sigma$ is the standard deviations

Radiological hazard indices due to radionuclides in the farm soils

Eqs. 9, 10, 11 and 12 were respectively used to determine the radium equivalent activity $\left(\mathrm{Ra}_{\mathrm{eq}}\right)$, external hazard index $\left(\mathrm{H}_{\mathrm{ex}}\right)$, internal hazard index $\left(\mathrm{H}_{\text {in }}\right)$ and gamma index $\left(\mathrm{I}_{\gamma}\right)$ in the farm soils from Ofada, Abakaliki and Aramoko and the results are presented in Table 3. From a radiological and safety perspective, the radium equivalent activity in any material for building construction must be less than or equal to $370 \mathrm{~Bq} / \mathrm{kg}$ i.e. $\mathrm{Ra}_{\mathrm{eq}} \leq 370 \mathrm{~Bq} / \mathrm{kg}$ (2).The mean radium equivalent activity of farm soils from each of the communities was lower than $370 \mathrm{~Bq} / \mathrm{kg}$, thus the use of the farm soils for construction of human dwellings is not expected to pose any serious radiological effect.
From a radiological point of view, the external hazard index, internal hazard index and gamma index of any building material must respectively be less than one(2). The values of $\mathrm{H}_{\mathrm{ex}}$, $\mathrm{H}_{\mathrm{in}}$, and $\mathrm{I}_{\gamma}$ in the farm soils from each study area were less than one, therefore no radiological health effect is expected when the soils are used for construction of human dwellings. The profile of $\mathrm{Ra}_{\mathrm{eq}}, \mathrm{H}_{\mathrm{ex}}, \mathrm{H}_{\text {in }}$, and $\mathrm{I}_{\gamma}$ with reference to farm land number in Ofada, Abakaliki and Aramoko are respectively shown in Figs. 3, 4 and 5. The shaded area in each Figure showed the standard deviation (departure) from the mean and the line at the middle of the shaded area indicated the mean

Table 3.Radiological hazard indices due to activity concentrations of the farm soils

\begin{tabular}{ccccccc}
\hline Community & No of farmlands & & $\mathrm{Ra}_{\mathrm{eq}}(\mathrm{Bq} / \mathrm{kg})$ & $\mathrm{H}_{\mathrm{in}}$ & $\mathrm{H}_{\mathrm{ex}}$ & $\mathrm{I}_{\gamma}$ \\
\hline \multirow{2}{*}{ Ofada } & \multirow{2}{*}{20} & Range & $43.46-60.24$ & $0.14-0.20$ & $0.12-0.16$ & $0.17-0.24$ \\
& & Mean $\pm \sigma$ & $50.95 \pm 4.87$ & $0.17 \pm 0.01$ & $0.14 \pm 0.01$ & $0.20 \pm 0.02$ \\
\multirow{2}{*}{ Abakaliki } & \multirow{2}{*}{20} & Range & $42.02-52.12$ & $0.14-0.17$ & $0.11-0.14$ & $0.16-0.20$ \\
& \multirow{2}{*}{ Aramoko } & Mean $\pm \sigma$ & $47.54 \pm 2.86$ & $0.16 \pm 0.01$ & $0.13 \pm 0.01$ & $0.18 \pm 0.01$ \\
& \multirow{2}{*}{20} & Range & $43.76-57.07$ & $0.15-0.18$ & $0.12-0.15$ & $0.17-0.22$ \\
& & Mean $\pm \sigma$ & $49.20 \pm 3.51$ & $0.16 \pm 0.01$ & $0.13 \pm 0.01$ & $0.19 \pm 0.01$ \\
\hline
\end{tabular}




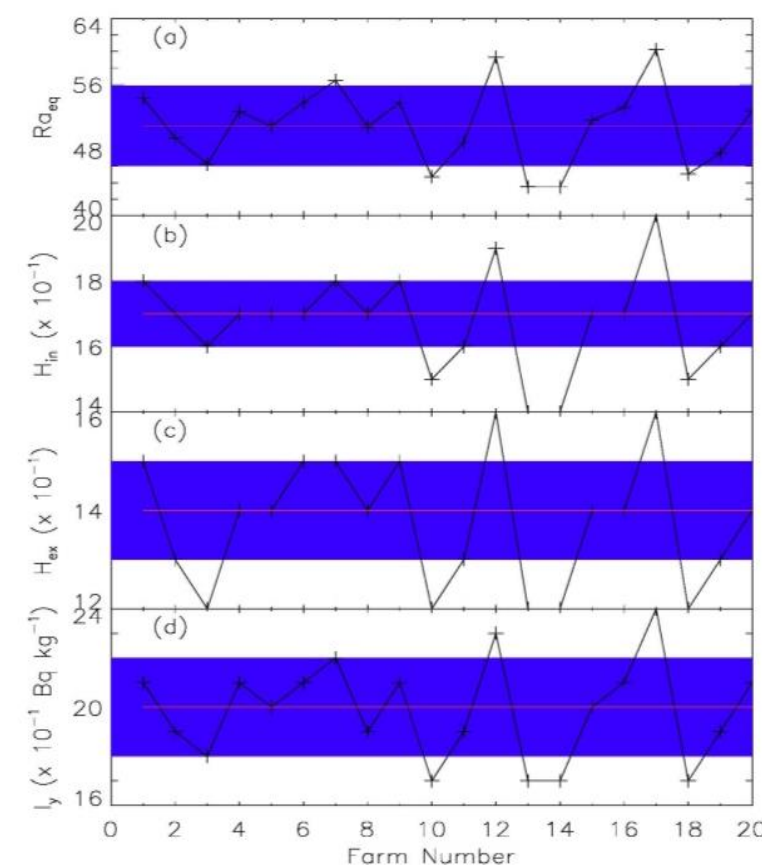

Figure 3. $\mathbf{R a}_{\mathrm{eq}}, \mathbf{H}_{\mathrm{in}}, \mathbf{H}_{\mathrm{ex}}$ and $\mathrm{I}_{\gamma}$ of farm soils from Ofada Community

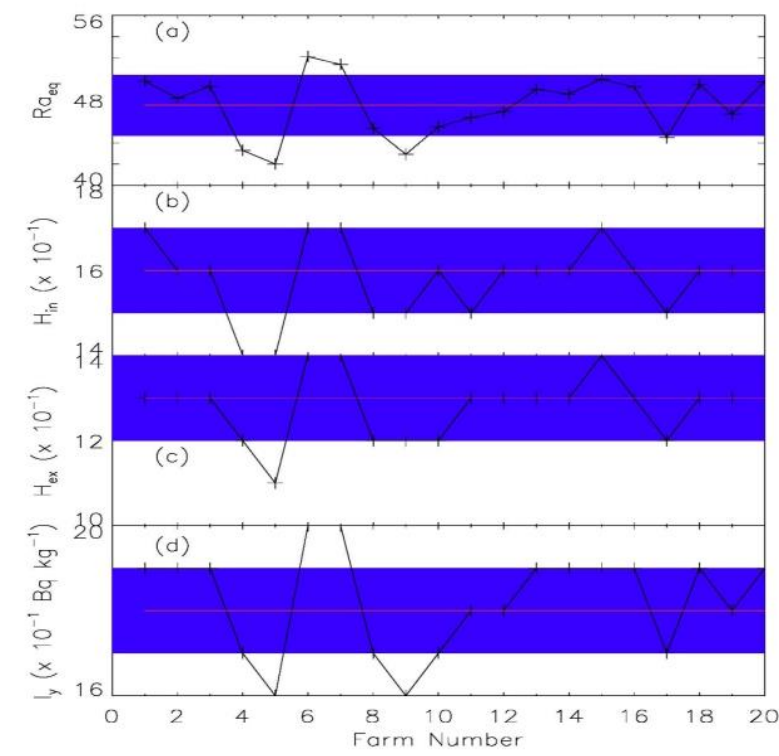

Figure 4: $\mathbf{R a}_{\mathrm{eq}}, \mathrm{H}_{\mathrm{in}}, \mathrm{H}_{\mathrm{ex}}$ and $I_{\gamma}$ of farm soils from Abakalilki Community

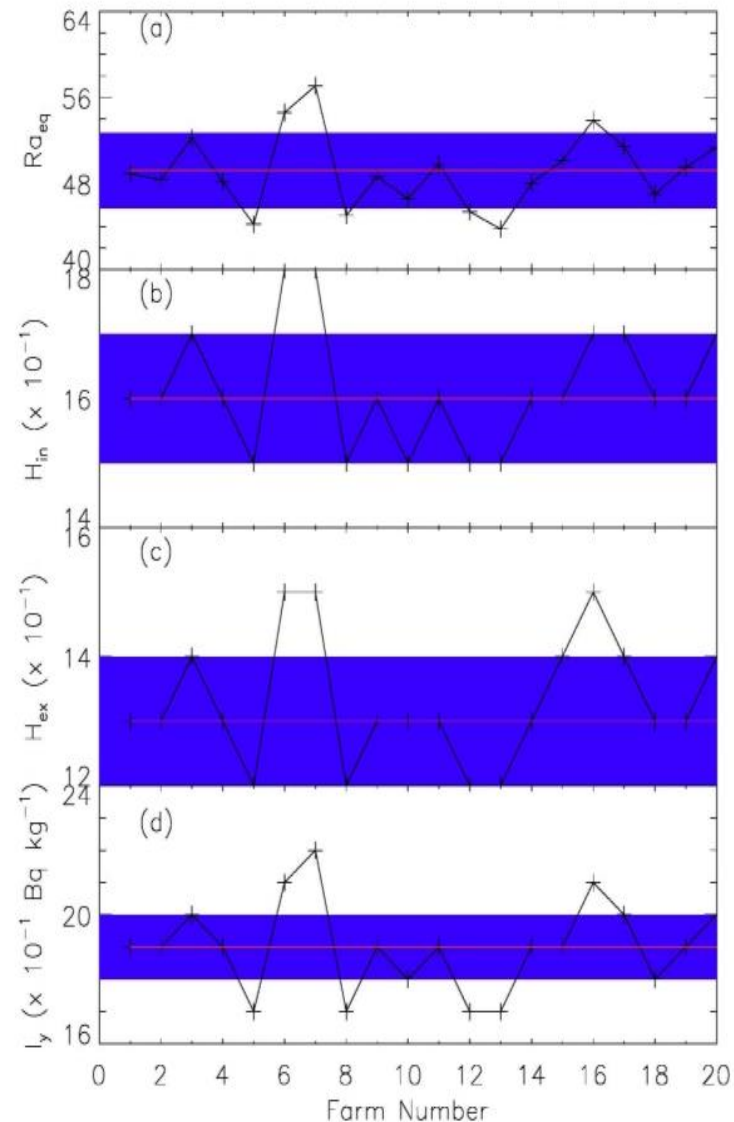

Figure 5. $\mathbf{R a}_{\mathrm{eq}}, \mathbf{H}_{\mathrm{in}}, \mathbf{H}_{\mathrm{ex}}$ and $\mathbf{I}_{\gamma}$ of farm soils from Aramoko Community

\section{Conclusion:}

The activity concentrations of natural radionuclides ${ }^{40} \mathrm{~K},{ }^{226} \mathrm{Ra}$ and ${ }^{232} \mathrm{Th}$ in rice and the farm soil samples from Ofada, Abakaliki and Aramoko Communities have been measured using gamma-ray spectrometry method. The effective dose rates are estimated from the activity concentrations of the three natural radionuclides in the ofada rice. The gamma absorbed dose and effective dose rates due to external exposure from farm soil radioactivity are calculated. From the results, the mean radioactivity levels in the rice appear very close and this is attributed to the absorption pattern of the ofada rice irrespective of the geological setting of the areas. The radiological impact in the study is insignificant as the cancer risks due to ingestion of the ofada rice and the farm soils in the study are low when compared to the United Nations Scientific Committee on the Effects Atomic Radiation (UNSCEAR) recommended value of $0.29 \times 10^{-3}$.

\section{Acknowledgment:}

The authors are thankful to the Radioactivity Measurement Laboratory, Department of Pure and Applied Physics, Ladoke Akintola 
University of Technology Ogbomosho for allowing us to use the gamma-ray spectrometry system for the study.

\section{Authors' declaration:}

- Conflicts of Interest: None.

- We hereby confirm that all the Figures and Tables in the manuscript are ours. Besides, the Figures and images, which are not ours, have been given the permission for re-publication attached with the manuscript.

- Ethical Clearance: The project was approved by the local ethical committee in Olabisi Onabanjo University.

\section{References:}

1. El-Taher A, Madkour HA. Environmental studies and radio-ecological impacts of Anthropogenic areas: shallow marine sediments Red Sea, Egypt. Isot Environ Healt S. 2014; 50(1):120-33

2. Jibiri NN, Alausa SK, Farai IP. Radiological hazard indices due to activity concentrations of natural radionuclide in farm soil from two high background radiation areas in Nigeria. IJLR.2009; 16:79-95

3. Bolca MU, Sac MM, Cokuysal BU, Karalı T, Ekdal EL. Radioactivity in soils and various foodstuffs from the Gediz River Basin of Turkey. Radiation Measurements. 2007 Feb 1;42(2):263-70.

4. Alzubaidi G, Hamid F, Abdul Rahman I. Assessment of natural radioactivity levels and radiation hazards in agricultural and virgin soil in the state of Kedah, North of Malaysia. The Scientific World Journal. 2016;2016.

5. Abdalsattar K. H, Laith A. Najam.A Radioactivity in Various Brands of Rice in Iraqi Market. J. Environ Monitor. 2015; 2(5): 70-5

6. Hernandez F, Hernandez-Armas J, Catalan A, Fernandez-Aldecoa JC, Landeras MI. Activity concentrations and mean annual effective dose of foodstuffs on the island of Tenerife, Spain. Radiat Prot Dosimmetry.2004; 111: 205-10

7. United Nations Scientific Committee on the Effects of Atomic Radiation (UNSCEAR). United Nations Scientific Committee on the Effects of Atomic Radiation. UNSCEAR 2000 Report to the General Assembly, New York: United Nations.

8. Mlwilo NA, Mohammed NK, Spyrou NM. Radioactivity levels of staple foodstuffs and dose estimates for most of the Tanzanian population, J. Radiol Prot. 2007; 27:471-80

9. Laith A. Najam, Nada F. Tawfiq, Fouzey H. Kitha. Measuring radioactivity level in various types of rice using $\mathrm{NaI}(\mathrm{Tl})$ detector. Am J Eng Res. 2015; 4(3): 126-32

10. Abojassim AA, Hady HN, Mohammed ZB. Natural radioactivity levels in some vegetables and fruits commonly used in Najaf Governorate Iraq. J. Bioen. Food Sci. 2016; 3(3): 113-23.

11. Nwankpa AC. Determination of Food Crops Contamination in Osun State, Nigeria Due to
Radium-226, Thorium-232 and Potassium-40 Concentrations in the Environment, Eur J Sustain Dev. 2017; 6(4): 169-74

12. Ashikun N, Khandoker A, Moinul IM, Mashiur RMD, Mahfuza B. Assessment of natural radioactivity in rice and their associated population dose estimation, Radia Eff Defect S. 2018; 173(1112): 1105-14.

13. Arogunjo AM, Farai IP, Fuwape AI. Dose rate assessment of terrestrial gamma radiation in Delta region Nigeria, Radiat Prot Desmetry 2004; 108: 73-7

14. Nigerian Geological Survey Agency. Southwestern Nigeria Zonal Map. NGSA Publishing (2009).

15. Omotayo Am, Elemo K, Oyedepo KO.Mapping of Ofada Rice Production Area, Monograph Series No 15, A Report of a study commissioned by Prop Com, 40 Mississippi St., Maitama, Abuja, Nigeria 2007

16. Omonona BT, Lawal JO, Oyebiyi ID. Profitability of production and resource-use efficiency among ofada rice (Oryza sativa japonica) farmers in Southwest, Nigeria. Comunicata Scientiae. 2012; 3: 104-7

17. Anounye JC, Danbaba N, Gana AS, Abo ME, Gregorio G, Oladimeji AO, et. al. Definition of ofada rice qualities through varietal identification and testing, Monograph Series \#26 NRCI \& WARDA. Maitama, Nigeria. 2007

18. Osaretin A, Ebuehi T, Oyewole AC, Effect of cooking and soaking on physical characteristics, nutrient composition and sensory evaluation of indigenous and foreign rice varieties in Nigeria. Afr $\mathbf{J}$ Biotechnol. 2007; 6: 1016-20

19. Tareq Alrefae, Tiruvachi N. Nageswaran. Radioactivity of long-lived gamma emitters in rice consumed in Kuwait. J Assoc Arab Univ Basic Appl. 2013; 13: 24-7

20. Jibiri NN, Farai IP, Alausa SK. Estimation of annual effective dose due to natural radioactive elements in ingestion of foodstuffs in tin mining area of JosPlateau, Nigeria. J Environ Radiact. 2007. 94: 31-40

21. Radioactivity in Food and the Environment (RIFE). The Center for Environment, Fisheries and Aquaculture Science. Radioactivity in food and the environment report. 2005 RIFE-10

22. Food Agriculture Organization (FAO), Compilation of Food Agriculture Organization annual consumption data/food balance sheet for Nigeria. A publication of Federal Office of Statistics (FOS) Nigeria, 2015

23. Usikalu MR, Onumejor CA, Akinpelu A, Achuka JA, Omeje M, Oladapo OF. Natural radioactivity concentration and its health implication on dwellers in selected locations of Ota. Environ Earth Sci. 2018; 173: $1-9$

24. World Health Organization. Meeting the MDG drinking water and sanitation target: the urban and rural challenges of the decade, WHO Library Catalogue-in-Publication Data 2008

25. Environmental Protection Agency (EPA), Cancer risk coefficients for Environmental Exposure to Radionuclides, United States Environmental Protection Agency. 1999. Report No -13 (EPA. 402 R-99-001). 
26. Alausa SK, Eluyera FO, Coker JO. Evaluation of radiation doses and hazard indices in crushed rocks from some quarries in Ibadan, Southwestern Nigeria. Radiat Prot Dosimetry. 2019; 1-7

27. Chandrasekaran A, Ravisankar R, Senthilkuma G, Thillaivelavan K, Dhinakaran B, Vijayagopal P, et al. Spatial distribution and lifetime cancer risk due to gamma radioactivity in Yelagiri Hills, Tamilnadu, India. Egypt. J Basic Appl Sci. 2014; 1(1): 38-48

28. Tufail M, Akhtar N, Javied S, Hamid T. Natural radioactivity hazards of building bricks fabricated from saline soil of two districts of Pakistan. J Radiol Prot.2007; 27: 481-92.

29. European Commission (EC), Radiological Protection Principles Concerning the Natural Radioactivity of Building Materials. 1999 Radiation Protection 112, Brussels, Belgium

30. Asaduzzaman KH, Khandaker MU, Amin YM, Mahat R. Uptake and distribution of natural radioactivity in rice from soil in north and west part of Peninsular Malaysia for the estimation of ingestion dose to man. Ann Nucl Energy.2015; 76: 85-93

31. Saeed MA, Wahab NAA, Hossain I, Ahmed R, Abdullah HY, Ramli AT, et al. Measuring radioactivity level in various types of rice using Hyper-pure germanium HPGe) detector, Int J Phys Sci. 2011; 6: 7335-40.

32. Raghavendra T, Vishwaprasad K, Kalyani G, Vijayalakshmi T, Himabindu V, Arunachalam J, et al. Assessment of Natural Radioactivity in Soils around the Proposed Uranium Mining Site of Lambapur Peddagattu and Seripally, J Geol Soc India . 2019; 93:223-7

33. Jagadeesha BG, Narayana Y. Natural radionuclide concentration in Hassan district of South India. India. J Radiat Res Appl Sc. 2017; 10(3) 283-8
34. Gyuk PM, Habila SS, Dogara MD, Kure N, Daniel HI, Handan TE. Determination of radioactivity levels in soil samples at Chikun environment of Kaduna Metropolis using gamma-ray spectrometry. Sci World J. 2017; 12(2): 52-5

35. Ademola AK, Bello AK, Adejumobi AC. Determination of natural radioactivity and hazard in soil samples in and around gold mining area in Itagunmodi, south-western, Nigeria. J Radiat Res Appl Sc. 2014; 7(3): 249-55

36. Jibiri NN, Bankole OS. Soil radioactivity and radiation absorbed dose rates at roadsides in hightraffic density area in Ibadan metropolis, southwestern Nigeria, Radiat Prot Dosemetry. 2006; 118: 453-8.

37. Oyebanjo OA, Falayi EO, Ogunsanwo FO, Odudu AI. Natural Radioactivity and Hazards in Soil Samples in Alade Community, Southwestern Nigeria. CJPL. 2018; 1(1): 18-28

38. Ademola JA, Exposure to high background radiation level in the tin mining area of Jos Plateau Nigeria. J Radiot Pot. 2008; 28:93-9

39. Taskin H, Karavus M, Ay P, Topuzoghi A, Hidiroghi S, Karahan G. Radionuclide concentration in soil and lifetime cancer risk due to gamma radioactivity in Kirlareli, Turkey. J Environ Radioactivity. 2009; 100: 49-53 


\title{
تقييم التأثير الإشعاعي للتربة الزراعية للرز أوفادا(الرز الاسيوي الياباني)من ثلاثة مناطق في نيجيريا
}

\author{
كولا اودونايكي 1
}

\author{
بايو الديلوجا \\ 1 شمس الاين الاوسا 1
}

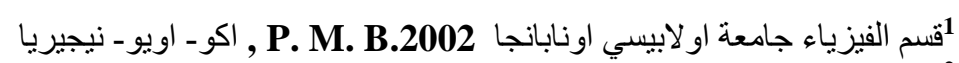

2 قسم الفيزياء و الاكترونيات كلية يابا التنقية - يايا ولاية لاكوس - نيجيريا

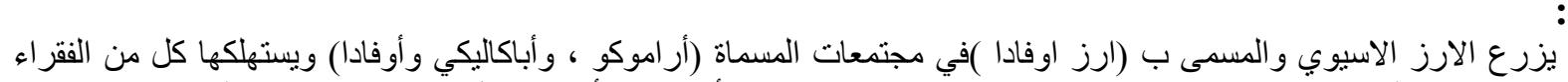

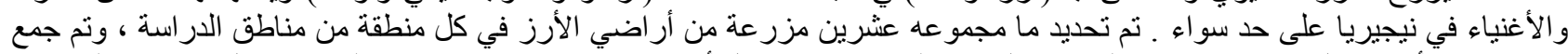

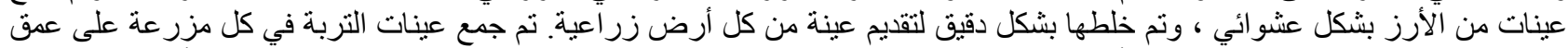

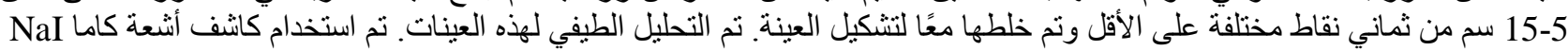

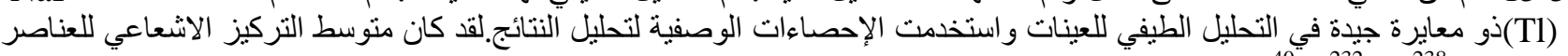

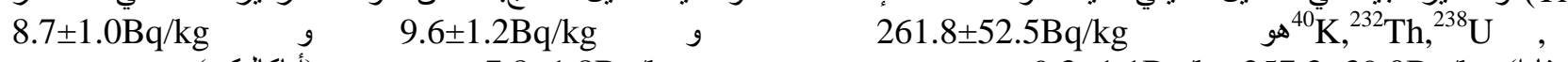

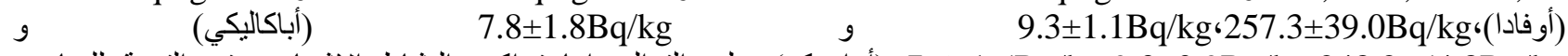

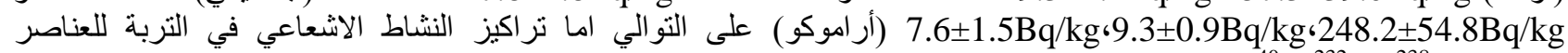

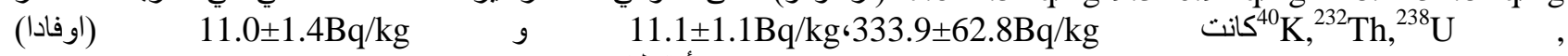

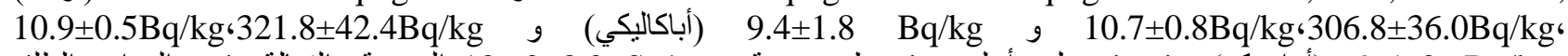

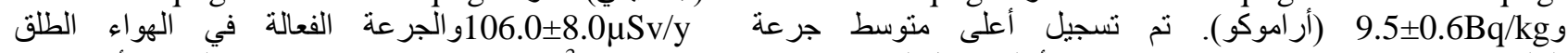

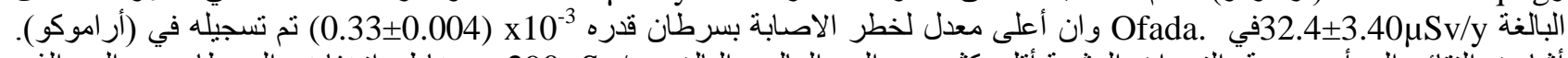

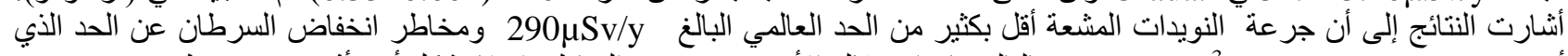

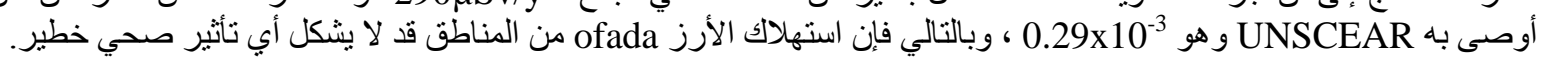
الكلمات المفتاحية: تربة المزرعة، نيجيريا، أرز أوفادا، المناطق المنتجة، التأثير الإشعاعي. 